\title{
Carcass and non-carcass components of Santa Ines lambs subjected to food restriction
}

\section{Componentes carcaça e não carcaça de cordeiros Santa Inês submetidos à restrição alimentar}

\author{
Adrielle Albuquerque dos Santos ${ }^{1}$; Patrícia Guimarães Pimentel ${ }^{2 *}$; \\ Elzânia Sales Pereira ${ }^{3}$; Guilherme Rocha Moreira ${ }^{4}$; \\ José Antônio Delfino Barbosa Filho5; Ivone Yurika Mizubuti'; \\ Edson Luis de Azambuja Ribeiro7; Dayanne Lima de Sousa ${ }^{1}$
}

\begin{abstract}
The objective of this study was to evaluate the effect of sex class (castrated; non-castrated) and level of food restriction $(0 \%, 30 \%$ and $60 \%$ of ad libitum consumption) on the quantitative composition of carcass and non-carcass components of Santa Ines lambs. A completely randomized 3x2 design (restriction level x sex class) was used to evaluate thirty lambs approximately two months of age with an average initial body weight of $13 \pm 1.49 \mathrm{~kg}$. When the average body weight of the animals in one of the treatment groups reached $28 \mathrm{~kg}$, all animals were slaughtered. Sex class had effect on body weight at slaughter, empty body weight, hot carcass weight and cold carcass weight. The weight of the leg was greater in non-castrated animals. There was linear decreased effect according to increasing levels of restriction for the carcass cuts, except for leg and rear loin yield. There was statistic difference between sex class for the weights of kidneys, paw and large intestine of non-castrated animals $(\mathrm{P}<0.05)$. Blood, head, leather, paw, rumen, reticulum, abomasum, small intestine, large intestine; perirenal, omental, mesenteric and heart fat showed linear decreased effect with the inclusion levels. The quantitative composition of carcass and non-carcass components of Santa Ines lambs is influenced by sex class and food restriction level.
\end{abstract}

Key words: Castration. Commercial cuts. Internal organs. Muscularity index. Sheep.

\section{Resumo}

Objetivou-se com o presente estudo avaliar o efeito de classe sexual (castrado e não castrado) e níveis de restrição alimentar $(0 \%, 30 \%$ e $60 \%$ do consumo ad libitum) sobre as características quantitativas dos componentes carcaça e não carcaça de cordeiros Santa Inês. Foi utilizado delineamento inteiramente casualizado $3 \times 2$ (nível de restrição x classe sexual) para avaliar trinta cordeiros, com aproximadamente dois meses de idade e peso corporal inicial médio de $13 \pm 1,49 \mathrm{~kg}$. Quando a média de peso corporal

\footnotetext{
${ }^{1}$ Discentes do Curso de Mestrado, Programa de Pós-graduação em Zootecnia, Universidade Federal do Ceará, UFC, Fortaleza, CE, Brasil. E-mail: albuquerque.zootecnia@gmail.com; dayannels@hotmail.com

2 Prof ${ }^{\mathrm{a}} \mathrm{Dr}^{\mathrm{a}}$, Dept ${ }^{\mathrm{o}}$ de Zootecnia, UFC, Fortaleza, CE, Brasil. E-mail: pgpimentel@hotmail.com

${ }^{3}$ Prof $^{\mathrm{a}} \mathrm{Dr}^{\mathrm{a}}$, Dept ${ }^{\mathrm{o}}$ de Zootecnia, UFC, Bolsista de Produtividade do CNPq, Fortaleza, CE, Brasil. E-mail: elzania@hotmail.com

${ }^{4}$ Prof. Dr., Dept ${ }^{\circ}$ de Estatística e Informática, Universidade Federal Rural de Pernambuco, UFRPE, Recife, PE, Brasil. E-mail: guirocham@gmail.com

5 Prof. Dr., Dept ${ }^{\circ}$ de Eng ${ }^{a}$ Agrícola, UFC, Fortaleza, CE, Brasil. E-mail: zkdelfino@gmail.com

${ }^{6}$ Prof $^{a}$ Dr $^{a}$, Dept ${ }^{\circ}$ de Zootecnia, Universidade Estadual de Londrina, UEL, Londrina, PR, Brasil. E-mail: mizubuti@uel.br

7 Prof. Dr., Dept ${ }^{\circ}$ de Zootecnia, UEL, Bolsista de Produtividade do CNPq, Londrina, PR, Brasil. E-mail: elar@uel.br

*Author for correspondence
} 
dos animais de um dos tratamentos atingiu $28 \mathrm{~kg}$, todos os animais foram abatidos. Houve influência da classe sexual sobre o peso corporal ao abate, peso corporal vazio, peso de carcaça quente e peso de carcaça fria. $\mathrm{O}$ peso da perna mostrou-se maior para animais não castrados. Houve efeito linear decrescente de acordo com o aumento dos níveis de restrição para as características e cortes de carcaça, exceto para rendimento de perna e lombo posterior. Houve diferença entre classes sexuais para os pesos dos rins, patas e intestino grosso de animais não castrados. Sangue, cabeça, pele, pata, rúmen-retículo, abomaso, intestino delgado, intestino grosso e gorduras perirrenal, omental, mesentérica e do coração mostraram efeito linear decrescente para os níveis de restrição. As características quantitativas dos componentes carcaça e não carcaça de cordeiros Santa Inês são influenciadas pelas classes sexuais e níveis restrição alimentar.

Palavras-chave: Castração. Cortes comerciais. Índice de musculosidade. Órgãos internos. Ovinos.

\section{Introduction}

Most sheep farming in the northeast of Brazil passes through a long drought phases that cause problems such as a decrease in the quantity and quality of food available for animals, resulting in alternating periods of weight gain and weight loss, resulting in low overall productivity and poor quality carcasses. This situation has encouraged producers and food scientists to seek alternative methods of farming that would improve meat production in this region. It has been proposed that food restriction, which is used in goats (YÃNÉZ et al., 2006), bovines (FONTES et al., 2007) and sheep (ALMEIDA et al., 2011) to reduce spending on feed in drought periods and results in compensatory growth, might provide a low-cost alternative to current extensive sheep farming methods. It is important to determine that food restriction would not impair the quality of carcasses, the main link between the producer and the consumer.

During the period of food restriction metabolically active organs related to digestive function decrease in size. Metabolically active tissues such as liver and intestine are the most influenced by restriction which manifests as significant loss in weight (HORNICK et al., 2000). The type of forage and forage-concentrate ratio can also influence the development of noncarcass components, particularly those involved in digestion, such as the rumen and reticulum (MORENO et al., 2011).

Sexual class is another factor that influences the quality of carcasses. Carvalho et al. (2005) reported faster growth and higher carcass yield in non-castrated than castrated males. Non-castrated males have a more favorable productivity profile. This is more meat and lower fat content in animals of similar body weight (KLEIN JÚNIOR et al., 2008).

The body conformation of the animal depends on the proportion and condition of all components of body weight, thus making more fair trade for producers seeking total quality, benefiting consumers both at the lowest price as the improvement in the sanitary aspect (OSÓRIO et al., 2002). Investigation of non-carcass components is important because they generate extra income for small farmers and may provide an alternative supply of animal protein for underserved populations (MATTOS et al., 2006).

This study aimed to evaluate the effects of sex class and level of food restriction on the quantitative composition of carcass and noncarcass components of Santa Ines lambs.

\section{Material and Methods}

The trial was conducted at the Department of Animal Science, Federal University of Ceara, 
Brazil. During the experimental period the average temperature inside the stalls was $25.71{ }^{\circ} \mathrm{C}$ and the average relative humidity was $74.67 \%$ (data obtained from sensors connected to dataloggers installed at the experimental shed).

The thirty Santa Ines male lambs (15 castrated; 15 non-castrated) were about two months of age, with an average initial body weight (BW) of 13.00 $\pm 1.49 \mathrm{~kg}$. The animals were identified, dewormed and placed in individual stalls with feeding troughs to supply the diet and water.

After a 15-day adaptation period, the lambs were randomly allocated to the treatments, with 5 castrated and 5 non-castrated animals in each food restriction group $(0 \%, 30 \%$ and $60 \%$ of $a d$ libitum consumption). The experimental design was a completely randomized 3 (food restriction) x 2 (sex class) factorial design giving six treatment groups.
Food restriction was calculated according to the consumption of animals fed ad libitum $(0 \%$ restriction). Animals were fed on diets as total mixed rations (TMR) twice daily, at $08 \mathrm{~h} 00$ and $16 \mathrm{~h} 00$. The animals in the $0 \%$ food restriction group received diets formulated to produce a mean daily weight gain of $200 \mathrm{~g}$, with forage: concentrate ratio of 60:40 (NRC, 2007).

Forage and concentrate samples were dried in a forced air oven at $55^{\circ} \mathrm{C}$ for $72 \mathrm{~h}$, then ground in a knife mill with a $1 \mathrm{~mm}$ screen (Wiley mill, Arthur H. Thomas, Philadelphia, PA, USA). The samples were analyzed for contents of dry matter (DM), ash, crude protein (CP) and ether extract (EE), according to AOAC (1990); neutral detergent fiber (NDF) and acid detergent fiber (ADF), according to Van Soest et al. (1991). The chemical-bromatological composition of Tifton-85 hay, ingredients and diet are shown in Tables 1 and 2.

Table 1. Chemical-bromatological composition of the ingredients and concentrate, in $\mathrm{g} \mathrm{kgMS}^{-1}$.

\begin{tabular}{lcccc}
\hline Nutrient & Tifton-85 hay & Ground corn & Soybean meal & Concentrate \\
\hline DM & 929.58 & 900.57 & 901.22 & 897.51 \\
CP & 110.61 & 77.01 & 532.05 & 291.10 \\
Ash & 66.95 & 15.04 & 70.34 & 55.10 \\
EE & 15.32 & 66.30 & 11.84 & 32.11 \\
NDF $^{1}$ & 707.70 & 152.95 & 193.86 & 168.22 \\
NDFap & 673.52 & 141.28 & 128.03 & 123.37 \\
ADF & 352.97 & 25.96 & 85.96 & 57.76 \\
TC $^{1}$ & 807.12 & 841.65 & 385.77 & 621.68 \\
NFC $^{2}$ & 133.60 & 700.37 & 257.74 & 520.71 \\
\hline
\end{tabular}

DM: dry matter; CP: crude protein; EE: ether extract; NDF: neutral detergent fiber; NDFap: neutral detergent fiber corrected for ash and protein; ADF: acid detergent fiber; TC: total carbohydrates; NFC: non-fibrous carbohydrates. ${ }^{1 \% \mathrm{TC}}=100-(\% \mathrm{CP}+\% \mathrm{EE}$ $+\%$ Ash); Sniffen et al. (1992). ${ }^{2} \mathrm{NFC}=100-(\% \mathrm{NDFap}+\% \mathrm{NFC}+\% \mathrm{EE}+\% \mathrm{Ash})$; Weiss (1999). 
Table 2. Composition of the experimental diet.

\begin{tabular}{lr}
\hline Ingredient (\%NM) & \\
\hline Tifton 85 hay & 60 \\
Concentrate $^{1}$ & 40 \\
Ground corn & 20,07 \\
Soybean meal & 19.23 \\
Limestone & 0.19 \\
Dicalcium phosphate & 0.41 \\
Sodium chloride & 0.07 \\
Mineral premix ${ }^{2}$ & 0.03 \\
\hline Chemical components $\left(\mathrm{g} \mathrm{kgMS}^{-1}\right)$ & \\
\hline DM & 918.10 \\
CP & 184.14 \\
Ash & 56.53 \\
EE & 24.60 \\
NDF & 492.60 \\
NDFap & 456.49 \\
ADF & 233.52 \\
TC & 727.37 \\
NFC & 270.29 \\
TDN & 558.00 \\
\hline
\end{tabular}

${ }^{1}$ Centesimal concentration in relation to the concentrated portion of the diets. ${ }^{2}$ Composition: Ca 7.5\%; P 3\%; Fe 16.500 ppm, Mn 9.750 ppm, Zn 35.000 ppm, I 1.000 ppm, Se 225 ppm, Co 1.000 ppm. DM: dry matter; CP: crude protein; EE: ether extract; NDF: neutral detergent fiber; NDFap: neutral detergent fiber corrected for ash and protein; $\mathrm{ADF}$ : acid detergent fiber; TC: total carbohydrates; NFC: non-fibrous carbohydrates; TDN: Total digestible nutrients.

Animals were weighed every 15 days to calculate average daily gain (ADG). The trial lasted 100 days, until the mean body weight (BW) of one of the treatment groups reached $28 \mathrm{~kg}$; which occurred when the animals had an approximate age of 175 days. At this moment all the animals were slaughtered.

Before slaughter, animals were weighed and then subjected to an 18-hour fast (no solid food or water) and then weighed again to obtain body weight at slaughter (BWS). At slaughter, lambs were stunned using a cash knocker and killed by exsanguination from jugular vein. Immediately after bleeding, the digestive tract was completely removed and weighed full. The individual components: internal organs (liver; heart; lungs, trachea and esophagus; tongue; bladder; kidneys; reproductive tract; spleen), digestive tract (rumen; reticulum; omasum; abomasum; small intestine; large intestine) and fat (omental; mesenteric; perirenal; pericardial) were weighed separately from the body. The contents of the gastrointestinal tract (GIC), bladder (B) and gallbladder (GB) were emptied, washed and drained and then weighed again to obtain the empty body weight (EBW) using the formula $\mathrm{EBW}=\mathrm{BWS}-(\mathrm{GIC}+\mathrm{B}+\mathrm{GB})$. The legs, head and other internal components were removed and weighed. The carcass was then weighed, and this value, the hot carcass weight (HCW), was used to calculate hot carcass yield (HCY) from the relation between the $\mathrm{HCW}$ and BWS. The carcasses were then cooled at $4^{\circ} \mathrm{C}$ for $24 \mathrm{~h}$.

After the cooling period, the carcasses were weighed, this value was the cold carcass weight (CCW). Loss by cooling (LC) was calculated: $\mathrm{LC}(\%)=[(\mathrm{HCW}-\mathrm{CCW}) / \mathrm{HCW}] \times 100$. The commercial carcass yield or cold carcass yield (CCY) was calculated as the ratio of CCW to BWS, expressed as a percentage. The biological yield (BY) was calculated using the formula BY $(\%)=$ HCW / EBW x 100. After weighing, the yield of non-carcass components (NCC\%) was calculated relative to the EBW, using the formula $\mathrm{NCC}(\%)=$ (NCC weight in kg / EBW) x 100.

The left half carcass was divided into eight anatomical regions (shoulder, leg, fore and rear loin, rib, neck, chest and flank), which were individually weighed to determine their percentage in relation of the whole carcass. The cuts were based on the system adopted by Monte et al. (2007).

Carcass musculature was assessed by determining the loin eye area (LEA) according to the method described by Müller (1987) and Cezar and Sousa (2007). The values obtained were inserted into the following formula to determine 
the LEA in $\mathrm{cm}^{2}$ : LEA $=(\mathrm{A} / 2 \times \mathrm{B} / 2) \times \pi$, where: $\pi$ $=3.1416$.

The normality and homoscedasticity of the distributions of variables were assessed using the Lilliefors and Bartlett tests respectively. All data were then subjected to analysis of variance. When there was no interaction, was applied the $\mathrm{F}$ test $(\mathrm{P}<0.05)$ for classes and regression analysis to restriction levels.

Statistical analyses were carried out using the $\mathrm{SAEG} \AA$ programs, according to procedures described by Ribeiro Júnior and Melo (2009); considering the effects of sex class, restriction level and the interaction between sex class and restriction level. Significance threshold of 5\% was applied to all comparisons.

\section{Results and Discussion}

There were no interactions between restriction level and sex class for carcass traits (Table 3). The non-castrated lambs showed higher BW, BWS, EBW, HCW and CCW than castrated animals. Non-castrated animals have a greater proportion of the hormone testosterone, which promotes muscle growth, thus producing a greater proportion of muscle mass and influencing the quality and carcass composition of lambs, such that the proportion of bone and muscle is higher, and the proportion of fat lower in non-castrated males than castrated males. According to Carvalho et al. (1999), sex class influences the growth rate and deposition of body tissues in various animals, with the highest growth rates in non-castrated males, followed by castrated males, then females.

Table 3. Mean initial body weight (IBW), body weight (BW), empty body weight at slaughter (BWS), empty body weight (EBW), hot carcass weight ( $\mathrm{HCW})$, hot carcass yield (HCY), cold carcass weight $(\mathrm{CCW})$, cold carcass weight (CCY), biological yield (BY) and losses by cooling (LC) for Santa Ines lambs subjected to food restriction.

\begin{tabular}{|c|c|c|c|c|c|c|c|}
\hline \multirow{2}{*}{ Variable } & \multicolumn{2}{|c|}{ Sex class } & \multicolumn{3}{|c|}{ Level of restriction } & \multirow{2}{*}{$\mathrm{CV}^{1}$} & \multirow{2}{*}{$\mathrm{R}^{2}$} \\
\hline & Non-castrated & Castrated & $0 \%$ & $30 \%$ & $60 \%$ & & \\
\hline IBW & 13.11 & 13.10 & $13 . .06$ & 13.02 & 13.23 & - & - \\
\hline $\mathrm{BW}, \mathrm{kg}^{2}$ & $24.21^{\mathrm{a}}$ & $22.87^{\mathrm{b}}$ & 30.20 & 23.87 & 17.27 & 5.25 & 99.99 \\
\hline BWS, $\mathrm{kg}^{3}$ & $22.19^{\mathrm{a}}$ & $21.12^{b}$ & 27.68 & 22.09 & 15.84 & 5.19 & 99.90 \\
\hline EBW, $\mathrm{kg}^{4}$ & $17.92^{\mathrm{a}}$ & $16.94^{b}$ & 23.04 & 17.70 & 12.16 & 5.43 & 99.99 \\
\hline $\mathrm{HCW}, \mathrm{kg}^{5}$ & $10.01^{\mathrm{a}}$ & $9.47^{\mathrm{b}}$ & 13.02 & 9.91 & 6.64 & 6.34 & 99.98 \\
\hline $\mathrm{HCY}, \%^{6}$ & 44.68 & 44.40 & 47.02 & 44.93 & 41.93 & 5.34 & 98.32 \\
\hline $\mathrm{CCW}, \mathrm{kg}^{7}$ & $9.89^{\mathrm{a}}$ & $9.40^{\mathrm{a}}$ & 12.92 & 9.83 & 6.53 & 6.21 & 99.96 \\
\hline $\mathrm{CCY}, \%^{8}$ & 44.09 & 44.04 & 46.47 & 44.57 & 41.22 & 5.14 & 98.37 \\
\hline BY, $\%{ }^{9}$ & 55.65 & 55.69 & 56.50 & 56.01 & 54.59 & 2.92 & 99.91 \\
\hline $\mathrm{LC}, \%^{10}$ & 0.967 & 0.827 & 0.753 & 0.822 & 1.12 & 41.64 & 88.40 \\
\hline
\end{tabular}

${ }^{\mathrm{a}, \mathrm{b}} \mathrm{C}$ Means followed by different letters in the row are different by $\mathrm{F}$ test $(\mathrm{P}<0.05) .{ }^{1}$ Coefficient of variation $(\%) .{ }^{2} \mathrm{Y}=30.25-0.22$ $\mathrm{X} ;{ }^{3} \mathrm{Y}=27.79-0.20 \mathrm{X} ;{ }^{4} \mathrm{Y}=23.08-0.18 \mathrm{X} ;{ }^{5} \mathrm{Y}=13.04-0.11 \mathrm{X} ;{ }^{6} \mathrm{Y}=47.17-0.08 \mathrm{X} ;{ }^{7} \mathrm{Y}=12.95-0.11 \mathrm{X} ;{ }^{8} \mathrm{Y}=46.87-0.09 \mathrm{X} ;{ }^{9} \mathrm{Y}$ $=56.66-0.03 \mathrm{X} ;{ }^{10} \mathrm{Y}=0.72+0.06 \mathrm{X}$.

Food restriction had a linear decrease effect on BW, BWS, EBW, $\mathrm{HCW}, \mathrm{HCY}, \mathrm{CCW}, \mathrm{CCY}$ and $\mathrm{BY}$, indicating that food restriction can reduce the quality of carcass and hence its market value. For each $1 \%$ increase in the level of food restriction, LC increased by $0.06 \%$; this was in line with expectations as the carcasses of the food-restricted animals had less subcutaneous fat which probably facilitated water loss during the cooling period. 
Cezar and Sousa (2007) stated that higher weight at slaughter implies a heavier carcass and consequently a higher carcass yield; this may be because the components which make up the commercial carcass grow faster than the other components of the body in terms of live weight. The fastest growing non-carcass regions, such as head and paw, grow slower than the central body region. The trunk composes most of the carcass, so that the increases in body weight associated with the age of the animal results in higher carcasses yields (CEZAR; SOUZA, 2007).

Yãnéz et al. (2006) investigated the effect of food restriction on carcass characteristics in Saanen goats, reporting that $\mathrm{BWS}, \mathrm{EBW}, \mathrm{HCW}$ and $\mathrm{CCW}$ were negatively associated with food restriction. Almeida et al. (2011), evaluating compensatory growth in Santa Ines lambs fed three different diets (ad libitum intake; intake to maintain body weight; a period of food restriction followed by ad libitum intake), observed that animals subjected to food restriction had lower final live weights $(51.5 \mathrm{~kg})$ when compared to ad libitum intake $(58.3 \mathrm{~kg})$ and compensatory growth $(62.8 \mathrm{~kg})$.

In this study, HCY, CCY, BY and LC did not show differences between the sex classes. Osório et al. (2005), evaluating carcass morphology in vivo, production and commercial characteristics of Corriedale lambs, and Carvalho et al. (2005), studying hot carcass yield in Sussex lambs, in consonance with this research, did not find differences for sex classes.

The fore loin, weighted in $\mathrm{kg}$, was the only commercial cut that showed interaction $(\mathrm{P}<0.05)$ between sex class and level of food restriction (Table 4). Non-castrated animals, in the $0 \%$ restriction group, presented higher values of fore loin weight than castrated animals. The fore loin weight of non-castrated animals decreased 0.008 $\mathrm{kg}$ for every $1 \%$ increase in the level of restriction. Probably the animals subjected to $0 \%$ restriction consumed more food than the other groups and the amount of nutrients ingested was sufficient to supply the requirements of maintenance and production, thus revealing differences between the sex classes.

Table 4. Average fore loin weight $(\mathrm{kg})$ for Santa Ines lambs subjected to food restriction.

\begin{tabular}{lccc}
\hline & & Level of restriction & \\
\cline { 2 - 4 } Category & $0 \%$ & $30 \%$ & $60 \%$ \\
\cline { 2 - 4 } & & Fore loin $(\mathrm{kg})$ & 0.406 \\
Non-castrated $^{1}$ & $0.888^{\mathrm{A}}$ & 0.602 & 0.404 \\
Castrated $^{2}$ & $0.593^{\mathrm{B}}$ & 0.690 & \\
\hline
\end{tabular}

${ }^{\mathrm{A}, \mathrm{B}}$ Means followed by different letters in the column are different by $\mathrm{F}$ test $(\mathrm{P}<0.05)$. Coefficient of variation $=20.07$. ${ }^{1} \mathrm{Y}=0.873$ - $0.008 \mathrm{X} ; \mathrm{R}^{2}(\%)=98.85 .{ }^{2} \mathrm{Y}=$ not significant.

The weight and yield of the commercial cuts leg, shoulder, chest, ribs, flank, rear loin and neck, as for the fore loin yield did not show significant interaction between sex class and restriction level (Table 5). The mean weight (in $\mathrm{kg}$ ) of the leg cut was higher in non-castrated males $(\mathrm{P}<0.05)$, but its yield was not influenced by sex class. The leg is a noble cut that concentrates a large number of muscles; BWS and EBW were also higher in noncastrated animals than in castrated animals in this study, which may account for the difference in leg cut weights.

According to Cezar and Souza (2010), the proportions of the different cuts in the carcass are an important factor in market value. In this way, the 
higher proportion of cuts containing more muscle and the lower proportion containing a large amount of bones makes the carcass more commercially valuable. The shoulder, chest, ribs, flank and neck cuts was negatively influenced by food restriction; the greater the level of food restriction the less these cuts weighed. Nóbrega et al. (2013) studied compensatory growth in sheep subjected to different levels of food restriction $(0,20,40$ and $60 \%)$ and reported that the weight of various cuts decreased linearly as the level of restriction increased, even if restriction was followed by refeeding.

Table 5. Average weights $(\mathrm{kg})$ and yields (\%) for the leg, shoulder, chest, ribs, flank, neck, fore end rear loin of Santa Ines lambs subjected to food restriction.

\begin{tabular}{|c|c|c|c|c|c|c|c|}
\hline \multirow{2}{*}{ Variable } & \multicolumn{2}{|c|}{ Sex Class } & \multicolumn{3}{|c|}{ Level of restriction } & \multirow{2}{*}{$\mathrm{CV}^{1}$} & \multirow{2}{*}{$\mathrm{R}^{2}$} \\
\hline & Non-castrated & Castrated & $0 \%$ & $30 \%$ & $60 \%$ & & \\
\hline Leg, $\mathrm{kg}^{2}$ & $1.727^{\mathrm{a}}$ & $1.637^{\mathrm{b}}$ & 2.192 & 1.734 & 1.176 & 5.90 & 99.25 \\
\hline Leg, $\%^{3}$ & 34.782 & 35.028 & 33.906 & 34.983 & 35.839 & 3.32 & 99.54 \\
\hline Shoulder, $\mathrm{kg}^{4}$ & 0.955 & 0.915 & 1.212 & 0.951 & 0.672 & 6.81 & 99.97 \\
\hline Shoulder, $\%{ }^{5}$ & 19.748 & 19.671 & 18.787 & 19.396 & 20.858 & 7.15 & 94.62 \\
\hline Chest, $\mathrm{kg}^{6}$ & 0.415 & 0.380 & 0.556 & 0.409 & 0.246 & 14.38 & 99.91 \\
\hline Chest, $\%^{7}$ & 8.377 & 7.956 & 8.597 & 8.349 & 7.617 & 14.36 & - \\
\hline $\mathrm{Rib}, \mathrm{kg}^{8}$ & 0.263 & 0.247 & 0.382 & 0.250 & 0.147 & 20.63 & 99.49 \\
\hline Rib, $\%{ }^{9}$ & 5.220 & 5.059 & 5.889 & 5.063 & 4.550 & 16.03 & 98.19 \\
\hline Flank, $\mathrm{kg}^{10}$ & 0.291 & 0.276 & 0.391 & 0.294 & 0.177 & 11.60 & 99.68 \\
\hline Flank, $\%{ }^{11}$ & 5.841 & 5.813 & 6.040 & 5.991 & 5.472 & 8.91 & 81.56 \\
\hline Neck, $\mathrm{kg}^{12}$ & 0.376 & 0.343 & 0.493 & 0.355 & 0.245 & 20.91 & 99.62 \\
\hline Neck, $\%{ }^{13}$ & 7.590 & 7.328 & 7.606 & 7.204 & 7.601 & 17.93 & - \\
\hline Fore loin, $\%{ }^{14}$ & 12.750 & 13.411 & 13.557 & 13.154 & 12.559 & 11.49 & - \\
\hline Rear loin, $\mathrm{kg}^{15}$ & 0.232 & 0.216 & 0.277 & 0.241 & 0.166 & 18.28 & 96.18 \\
\hline Rear loin, $\%{ }^{16}$ & 4.773 & 4.871 & 4.258 & 4.925 & 5.160 & 16.19 & 92.95 \\
\hline
\end{tabular}

${ }^{\mathrm{a}, \mathrm{b}}$ Means followed by different letters in the row are different by $\mathrm{F}$ test $(\mathrm{P}<0.05) .{ }^{1}$ Coefficient of variation $(\%) .{ }^{2} \mathrm{Y}=2.208-0.117$ $\mathrm{X} ;{ }^{3} \mathrm{Y}=33.943+0.032 \mathrm{X} ;{ }^{4} \mathrm{Y}=1.214-0.009 \mathrm{X} ;{ }^{5} \mathrm{Y}=18.644-0.035 \mathrm{X} ;{ }^{6} \mathrm{Y}=0.559-0.005 \mathrm{X} ;{ }^{8} \mathrm{Y}=0.377-0.004 \mathrm{X} ;{ }^{9} \mathrm{Y}=5.835-$ $0.022 \mathrm{X} ;{ }^{10} \mathrm{Y}=0.394-0.004 \mathrm{X} ;{ }^{11} \mathrm{Y}=6.120-0.009 \mathrm{X} ;{ }^{12} \mathrm{Y}=0.488-0.004 \mathrm{X} ;{ }^{15} \mathrm{Y}=0.248-0.002 \mathrm{X} ;{ }^{16} \mathrm{Y}=4.329+0.015 \mathrm{X} ;{ }^{7,13}{ }^{14}$ not significant.

In this study, chest, neck and fore loin yields were unaffected by food restriction. These results are consistent with the law of anatomical harmony, which states that the proportions of the various cuts will be similar across carcasses even with different weights, possibly due to the differences in the development of tissues, such as muscle and fat.

Food restriction increased leg and rear loin cuts yields this is greater food restriction resulted in an increase in the proportion of half carcass weight made up by those cuts. Immediately after birth many of the muscle groups of the lower limb, such as semi-membranous muscles, grow much faster than the muscle mass as a whole and this group of muscles quickly comes to make up a greater proportion of total muscle mass than at birth (BUTTERFIELD, 1988). In lambs subjected to $60 \%$ food restriction, this muscle group is proportionally the largest component of muscle mass when the animal weighs around $20 \%$ of its adult mass. As the animals continue to grow, the relative weight of lower limb muscle decreases gradually as the relatively high growth rate in this muscle group is gradually overtaken by the growth of the muscles 
as a whole. Other muscle groups increase rapidly in mass to fulfill the functional requirements of the developing animals. The muscles located around the spine presents the same behavior, because the longissimus and psoas major comprise about $60 \%$ of the weight of the muscle group and their growth patterns have a profound influence on the growth and maturation of the group as a whole.

There was no interaction between restriction level and sex class for the LEA although food restriction had a negative effect on LEA (Table 6). This finding was unsurprising as most of the carcass variables studied for instance BWS, EBW, $\mathrm{HCY}, \mathrm{CCY}$, cuts and carcass measurements were also sensitive to feed decrease. These results indicate that very high levels of food restriction can compromise carcass quality in lambs. Urano et al. (2006) reported a mean LEA of $14.8 \mathrm{~cm}^{2}$ in Santa Ines lambs fed with increasing levels of whole soybean, higher than the obtained in this study.

Table 6. Mean loin eye area (LEA) in Santa Ines lambs subjected to food restriction.

\begin{tabular}{|c|c|c|c|c|c|c|c|}
\hline \multirow{2}{*}{ Variable } & \multicolumn{2}{|c|}{ Sex class } & \multicolumn{3}{|c|}{ Level of restriction } & \multirow{2}{*}{$\mathrm{CV}^{1}$} & \multirow{2}{*}{$\mathrm{R}^{2}$} \\
\hline & Non-castrated & Castrated & $0 \%$ & $30 \%$ & $60 \%$ & & \\
\hline LEA $^{2}$ & 8.934 & 9.082 & 11.692 & 9.041 & 6.616 & 20.12 & 99.97 \\
\hline
\end{tabular}

${ }^{1}$ Coefficient of variation (\%). ${ }^{2} \mathrm{Y}=11.602-0.084 \mathrm{X}$.

There was a linear negative association between restriction level and heart weight and yield and respiratory system weight (Table 7). These results conflict with those of Moreno et al. (2011) who stated that the yields of vital organs such as the respiratory tract, brain and heart were, unlike organs related to digestion and metabolism of food, not influenced by diet as they had priority in the use of nutrients and thus their integrity was robust against changes in the nutritional status of the animals.

Table 7. Average weights (kg) and yields (\%) of the heart, respiratory system (Resp. Syst.), liver, kidneys and spleen in Santa Ines lambs subjected to food restriction.

\begin{tabular}{|c|c|c|c|c|c|c|c|}
\hline \multirow{2}{*}{ Variable } & \multicolumn{2}{|c|}{ Sex class } & \multicolumn{3}{|c|}{ Level of restriction } & \multirow{2}{*}{$\mathrm{CV}^{1}$} & \multirow{2}{*}{$\mathrm{R}^{2}$} \\
\hline & Non-castrated & Castrated & $0 \%$ & $30 \%$ & $60 \%$ & & \\
\hline Heart, $\mathrm{kg}^{2}$ & 0.109 & 0.105 & 0.136 & 0.105 & 0.083 & 10.00 & 98.43 \\
\hline Heart, $\%{ }^{3}$ & 0.619 & 0.630 & 0.592 & 0.596 & 0.683 & 11.78 & 77.34 \\
\hline Resp. Syst., $\mathrm{kg}^{4}$ & 0.591 & 0.556 & 0.731 & 0.598 & 0.409 & 11.53 & 98.91 \\
\hline Resp. Syst., $\%^{5}$ & 3.282 & 3.325 & 3.171 & 3.375 & 3.351 & 8.51 & - \\
\hline Liver, $\mathrm{kg}^{6}$ & 0.315 & 0.297 & 0.447 & 0.287 & 0.200 & 9.06 & - \\
\hline Liver, $\%^{7}$ & 1.731 & 1.725 & 1.941 & 1.623 & 1.644 & 7.27 & - \\
\hline Kidneys, $\mathrm{kg}^{8}$ & $0.072^{\mathrm{a}}$ & $0.066^{\mathrm{b}}$ & 0.090 & 0.069 & 0.050 & 7.34 & 99.99 \\
\hline Kidneys, $\%{ }^{9}$ & 0.405 & 0.392 & 0.392 & 0.388 & 0.415 & 8.95 & - \\
\hline Spleen, $\mathrm{kg}^{10}$ & 0.039 & 0.038 & 0.053 & 0.038 & 0.027 & 16.34 & 98.59 \\
\hline Spleen, $\%{ }^{11}$ & 0.219 & 0.223 & 0.229 & 0.212 & 0.222 & 16.67 & - \\
\hline
\end{tabular}

${ }^{\mathrm{a}, \mathrm{b}}$ Means followed by different letters in the row are different by $\mathrm{F}$ test $(\mathrm{P}<0.05) .{ }^{1}$ Coefficient of variation $(\%) .{ }^{2} \mathrm{Y}=0.136-0.009$ $\mathrm{X} ;{ }^{3} \mathrm{Y}=0.578-0.01 \mathrm{X} ;{ }^{4} \mathrm{Y}=0.739-0.005 \mathrm{X} ;{ }^{8} \mathrm{Y}=0.090-0.007 \mathrm{X} ;{ }^{10} \mathrm{Y}=0.051-0.0004 \mathrm{X} ;{ }^{5,6,7,9,11}$ not significant. 
There were no interactions between restriction level and sex class for the heart, respiratory system, liver, kidneys and spleen (Table 7), however there were sex class differences in the weight of the kidneys.

We observed no significant changes in liver weight or yield, indicating that increasing the level of food restriction produced no reduction in the weight or performance of that organ, in contrast to Ferrell and Jenkins (1998) who observed that the liver exhibits a high metabolic rate because it participates actively in nutrient metabolism and therefore responds to reductions in food intake.

Non-castrated animals had heavier kidneys than castrated animals. Luchiari Filho (2000) noted that the carcasses of non-castrated animals have approximately $8 \%$ less fat and 38\% more muscular portion than those of castrated animals due to the action of the hormone testosterone. Kidneys participate actively in the excretion of substances and the carcasses of non-castrated animals are heavier than those of castrated animals, so this may account for the observed difference in kidney weight.

Spleen weight was negatively affected by food restriction (Table 7), as observed by Seebeck's (1967) in a study with bovines subjected to food restriction. The cited authors noted that one of the functions of the spleen is to store blood for release under stressful conditions. In this research, lower spleen weights may have been thus related to the concomitant reduction blood weight (Table 8).

Table 8. Average weights ( $\mathrm{kg}$ ) and yields (\%) for blood, head, leather, paw, omasum (OMA), abomasum, rumenreticulum (RURE), small intestine (SI) and large intestine (LI) in Santa Ines lambs subjected to food restriction.

\begin{tabular}{|c|c|c|c|c|c|c|c|}
\hline \multirow{2}{*}{ Variable } & \multicolumn{2}{|c|}{ Sex class } & \multicolumn{3}{|c|}{ Level of restriction } & \multirow{2}{*}{$\mathrm{CV}^{1}$} & \multirow{2}{*}{$\mathrm{R}^{2}$} \\
\hline & Non-castrated & Castrated & $0 \%$ & $30 \%$ & $60 \%$ & & \\
\hline Blood, $\mathrm{kg}^{2}$ & 1.020 & 0.965 & 1.326 & 0.994 & 0.693 & 7.57 & 99.92 \\
\hline Blood, $\%^{3}$ & 5.681 & 5.706 & 5.767 & 5.614 & 5.704 & 7.73 & - \\
\hline Head, $\mathrm{kg}^{4}$ & 1.024 & 1.003 & 1.154 & 1.021 & 0.881 & 5.50 & 99.96 \\
\hline Head, $\% 5$ & 5.982 & 6.124 & 5.027 & 5.775 & 7.248 & 5.85 & - \\
\hline Leather, $\mathrm{kg}^{6}$ & 1.672 & 1.550 & 2.119 & 1.675 & 1.097 & 13.06 & 99.42 \\
\hline Leather, $\%^{7}$ & 9.284 & 9.157 & 9.194 & 9.449 & 9.024 & 10.25 & - \\
\hline Paw, $\mathrm{kg}^{8}$ & $0.564^{\mathrm{a}}$ & $0.539^{b}$ & 0.682 & 0.561 & 0.426 & 5.68 & 99.78 \\
\hline Paw, $\%{ }^{9}$ & 3.194 & 3.261 & 2.964 & 3.177 & 3.512 & 7.40 & 98.43 \\
\hline OMA, $\mathrm{kg}^{10}$ & 0.063 & 0.057 & 0.069 & 0.065 & 0.046 & 14.08 & - \\
\hline OMA, $\%^{11}$ & 0.361 & 0.340 & 0.300 & 0.367 & 0.380 & 11.02 & 88.18 \\
\hline Abomasum, $\mathrm{kg}^{12}$ & 0.085 & 0.079 & 0.010 & 0.078 & 0.070 & 22.62 & 94.18 \\
\hline Abomasum, $\%{ }^{13}$ & 0.495 & 0.485 & 0.434 & 0.446 & 0.582 & 19.62 & 81.80 \\
\hline RURE, $\mathrm{kg}^{14}$ & 0.500 & 0.496 & 0.619 & 0.526 & 0.362 & 12.06 & 97.78 \\
\hline RURE, $\%{ }^{15}$ & 2.827 & 2.958 & 2.683 & 2.979 & 2.988 & 10.44 & 76.72 \\
\hline SI, $\mathrm{kg}^{16}$ & 0.427 & 0.412 & 0.522 & 0.420 & 0.300 & 13.31 & 99.92 \\
\hline SI, $\%{ }^{17}$ & 2.398 & 2.448 & 2.404 & 2.380 & 2.477 & 15.33 & - \\
\hline LI, $\mathrm{kg}^{18}$ & $0.308^{\mathrm{a}}$ & $0.269^{b}$ & 0.370 & 0.272 & 0.233 & 13.23 & 94.80 \\
\hline LI, $\%{ }^{19}$ & 1.748 & 1.624 & 1.606 & 1.536 & 1.913 & 12.56 & - \\
\hline
\end{tabular}

${ }^{\mathrm{a}, \mathrm{b}}$ Means followed by different letters in the row are different by $\mathrm{F}$ test $(\mathrm{P}<0.05) .{ }^{1}$ Coefficient of variation $(\%) .{ }^{2} \mathrm{Y}=1.322-0.011$ $\mathrm{X} ;{ }^{4} \mathrm{Y}=1.155-0.004 \mathrm{X} ;{ }^{6} \mathrm{Y}=2.141-0.017 \mathrm{X} ;{ }^{8} \mathrm{Y}=0.658-0.004 \mathrm{X} ;{ }^{9} \mathrm{Y}=2.944-0.009 \mathrm{X} ;{ }^{11} \mathrm{Y}=0.309-0.001 \mathrm{X} ;{ }^{12} \mathrm{Y}=0.098-$ $0.0005 \mathrm{X} ;{ }^{13} \mathrm{Y}=0.412-0.002 \mathrm{X} ;{ }^{14} \mathrm{Y}=0.630-0.004 \mathrm{X} ;{ }^{15} \mathrm{Y}=2.731-0.005 \mathrm{X} ;{ }^{16} \mathrm{Y}=0.361-0.002 \mathrm{X} ;{ }^{18} \mathrm{Y}=0.550-0.004 \mathrm{X} ;{ }^{3,5,7}$, $10,17,19$ not significant. 
There were no interactions between sex class and restriction level for weights of blood, head, leather and paw. These variables were negatively affected by food restriction, an unsurprising result which was similar to the pattern of effects on carcass traits. The weight of the paw differed between sex classes (Table 8); non-castrated animals had a higher mean paw weight than castrated animals. The omasum, although participates actively in food digestion, was not influenced by food restriction, considering its weight in $\mathrm{kg}$.

There was no interaction between sex class and food restriction level in terms of the weights or yields of abomasum, rumen-reticulum or small or large intestine although food restriction was negatively associated with the weight and performance of these organs, possibly because they are directly involved in food digestion. Furlan et al. (2006) stated that the function of the small intestine is to absorb nutrients and that its size is proportional to the organism's body size and related to the type of food consumed. These authors suggested that experience of a vast dietary nutrient intake stimulates further development of the intestines, as nutrients that escape ruminal fermentation induce mitotic processes of intestinal villi. Hornick et al. (2000) also reported that highly metabolically active tissues such as the intestines were more affected by food restriction which manifested as large weight losses in these tissues, as observed in this study.

The data presented in Tables 7 and 8 show that feeding restrictions imposed on the lambs reduced the size of their internal organs and that this decrease may have been associated with lower basal metabolism.

There was no interaction between food restriction level and sex class influencing fats (Table 9). Fat deposits were negatively affected by food restriction, probably because nutrients taken in during feeding are converted into energy and excess energy is then transformed into muscle and adipose tissue (LISBOA et al., 2010). When food intake is lower the body produces less adipose tissue as the energy from food is used to meet the needs of the animal.

Table 9. Average values weights $(\mathrm{kg})$ and yields $(\%)$ for perirenal fat $(\mathrm{PF})$, omental fat (OF), mesenteric fat (MF) and heart fat (HF) in Santa Ines lambs subjected to food restriction.

\begin{tabular}{|c|c|c|c|c|c|c|c|}
\hline \multirow{2}{*}{ Variable } & \multicolumn{2}{|c|}{ Sex class } & \multicolumn{3}{|c|}{ Level of restriction } & \multirow{2}{*}{$\mathrm{CV}^{1}$} & \multirow{2}{*}{$\mathrm{R}^{2}$} \\
\hline & Non-castrated & Castrated & $0 \%$ & $30 \%$ & $60 \%$ & & \\
\hline $\mathrm{PF}, \mathrm{kg}^{2}$ & 0.117 & 0.121 & 0.184 & 0.107 & 0.081 & 30.02 & 92.38 \\
\hline $\mathrm{PF}, \%^{3}$ & 0.655 & 0.714 & 0.806 & 0.606 & 0.661 & 28.38 & - \\
\hline $\mathrm{OF}, \mathrm{kg}^{4}$ & 0.188 & 0.207 & 0.318 & 0.191 & 0.081 & 43.95 & 99.83 \\
\hline $\mathrm{OF}, \%^{5}$ & 0.970 & 1.260 & 1.379 & 1.086 & 0.663 & 38.94 & 98.91 \\
\hline MF, $\mathrm{kg}^{6}$ & 0.153 & 1.182 & 0.263 & 0.153 & 0.086 & 27.19 & 98.07 \\
\hline $\mathrm{MF}, \%^{7}$ & 0.827 & 0.984 & 1.141 & 0.866 & 0.698 & 22.89 & 98.16 \\
\hline $\mathrm{HF}, \mathrm{kg}^{8}$ & 0.035 & 0.039 & 0.060 & 0.031 & 0.019 & 38.72 & 94.58 \\
\hline $\mathrm{HF}, \%{ }^{9}$ & 0.179 & 0.201 & 0.247 & 0.171 & 0.158 & 30.19 & 86.25 \\
\hline
\end{tabular}

${ }^{1}$ Coefficient of variation $(\%) .{ }^{2} \mathrm{Y}=0.175-0.002 \mathrm{X} ;{ }^{4} \mathrm{Y}=0.315-0.004 \mathrm{X} ;{ }^{5} \mathrm{Y}=1.4-0.12 \mathrm{X} ;{ }^{6} \mathrm{Y}=0.255-0.003 \mathrm{X} ;{ }^{7} \mathrm{Y}=1.123-0.007$ $\mathrm{X} ;{ }^{8} \mathrm{Y}=0.057-0.0007 \mathrm{X} ;{ }^{9} \mathrm{Y}=0.236-0.001 \mathrm{X} ;{ }^{3}$ not significant. 


\section{Conclusion}

Food restriction negatively influences the quality of carcasses. Sex class affects quantitative carcass traits, with higher carcass and cut weights in noncastrated males. The weight and yield of the noncarcass components of growing Santa Ines lambs are influenced by sex class and food restriction level.

\section{Acknowledgments}

The authors wish to thank the CNPq (National Counsel of Technological and Scientific Development) for financial support (Proc. 304666/2012). The first author benefited from a grant from CAPES (Coordination for the Improvement of Higher Education Personnel).

\section{References}

ALMEIDA, T. R. V.; PEREZ, J. R. O.; CHLAD, M.; FRANÇA, P. M.; LEITE, R. F.; NOLLI, C. P. Desempenho e tamanho de vísceras de cordeiros Santa Inês após ganho compensatório. Revista Brasileira de Zootecnia, Viçosa, MG, v. 40, n. 3, p. 616-621, 2011.

ASSOCIATION OF OFFICIAL ANALYTICAL CHEMISTS - AOAC. Official methods of analysis. $15^{\text {th }}$ ed. Washington, D.C.: Ed Keneth Helrich, 1990. 1298 p.

BUTTERFIELD, R. New concept of sheep growth. Sydney: Sydney University Press, 1988. 167 p.

CARVALHO, S.; PIVATO, J.; VERGUEIRO, A.; KIELING, R.; TEIXEIRA, R. C. Desempenho e características quantitativas da carcaça de cordeiros da raça Suffolk, castrados e não castrados, terminados em confinamento. Revista Brasileira de Agrociência, Pelotas, v. 11, n. 1, p. 79-84, 2005.

CARVALHO, S.; PIRES, C. C.; PERES, J. R. R.; ZEPPENFELD, C.; WEISS, A. Desempenho de cordeiros machos não castrados, machos castrados e fêmeas, alimentados em confinamento. Ciência Rural, Santa Maria, v. 29, n. 1, p. 129-133, 1999.

CEZAR, M. F.; SOUSA, W. H. Proposta de avaliação e classificação de carcaças de ovinos deslanados e caprinos. Tecnologia \& Ciências Agropecuárias, João Pessoa, v. 4, n. 4, p. 41-51, 2010.
Carcaças ovinas e caprinas: obtenção, avaliação, classificação. Uberaba, MG: Ed. Agropecuária Tropical, 2007. 147 p.

FERRELL, C. L.; JENKINS, T. G. Body composition and energy utilization by steers of diverse genotypes fed a high-concentrate diet during the finishing period: Angus, Boran, Brahman, Hereford and Tuli Sires. Journal of Animal Science, Madison, v. 76, n. 2, p. 647657, 1998.

FONTES, C. A. A.; GUIMARÃES, R. F. M.; ALMEIDA, M. I. V.; CAMPOS, O. F.; ALMEIDA, F. Q.; SANT'ANA, N. F. Avaliação do ganho compensatório em novilhos mestiços Holandês-Gir: consumo e desempenho. Revista Brasileira de Zootecnia, Viçosa, MG, v. 36, n. 3, p. 698708, 2007.

FURLAN, R. L.; MACARI, M.; FARIA FILHO, D. E. Anatomia e fisiologia do trato gastrintestinal. In: BERCHIELLI, T. T.; PIRES, A. V.; OLIVEIRA, S. G. (Ed.). Nutrição de ruminantes. Jaboticabal: Funep, 2006. p. 1-23.

HORNICK, J. L.; VAN EENAEME, C.; GERARD, O. Mechanisms of reduced and compensatory growth. Domestic Animal Endocrinology, New York, v. 19, n. 2, p. 21-132, 2000.

KLEIN JÚNIOR, M. H.; SIQUEIRA, E. R.; ROÇA, R. O. Composição tecidual e qualidade da gordura na carne de cordeiros castrados e não castrados confinados sob dois fotoperíodos. Arquivos Brasileiros de Medicina Veterinária e Zootecnia, Belo Horizonte, v. 60, n. 2, p. 461-469, 2008.

LISBOA, A. C. C.; FURTADO, D. A.; MEDEIROS, A. N.; COSTA, R. G.; QUEIROGA, R. C. E.; BARRETO, L. M. G. Quantitative characteristics of the carcasses of Moxotó and Canindé goats fed diets with two different energy levels. Revista Brasileira de Zootecnia, Viçosa, MG, v. 39, n. 7, p. 1565-1570, 2010.

LUCHIARI FILHO, A. Pecuária da carne bovina. São Paulo: LinBife, 2000. 134 p.

MATTOS, C. W.; CARVALHO, F. F. R.; DUTRA JÚNIOR, W. M.; VÉRAS, A. S. C.; BATISTA, A. M. V.; ALVES, K. S.; RIBEIRO, V. L.; SILVA, M. J. M. S.; MEDEIROS, G. R.; VASCONCELOS, R. M. J.; ARAÚJO, A. O.; MIRANDA, S. B. Características de carcaça e dos componentes não carcaça de cabritos Moxotó e Canindé submetidos a dois níveis de alimentação. Revista Brasileira de Zootecnia, Viçosa, MG, v. 35, n. 5, p. 2125-2134, 2006. 
MONTE, A. L. S.; VILLARROEL, A. B. S.; PÉREZ, J. R. O.; ZAPATA, J. F. F.; BESERRA, F. J.; OLIVEIRA, A. N. Rendimento de cortes comerciais e composição tecidual da carcaça de cabritos mestiços. Revista Brasileira de Zootecnia, Viçosa, MG, v. 36, n. 6, p. 2127 2133, 2007. Suplemento.

MORENO, G. M. B.; SILVA SOBRINHO, A. G.; LEÃO, A. G.; PEREZ, H. L.; LOUREIRO, C. M. B.; PEREIRA, G. T. Rendimento dos componentes não carcaça de cordeiros alimentados com silagem de milho ou cana-deaçúcar e dois níveis de concentrado. Revista Brasileira de Zootecnia, Viçosa, MG, v. 40, n. 12, p. 2878-2885, 2011.

MÜLLER, L. Normas para avaliação de carcaças e concurso de carcaças de novilhos. 2. ed. Santa Maria: Imprensa Universitária, 1987. 31 p.

NATIONAL RESEARCH COUNCIL - NRC. Nutrient requirements of small ruminants: sheep, goats, cervids, and new world camelids. Washington, D.C.: The National Academies Press, 2007. 347 p.

NÓBREGA. G. H.; CÉZAR, M. F.; PEREIRA FILHO, J. M.; SOUSA, W. H.; SOUSA, O. B.; CUNHA, M. G. G.; SANTOS, J. R. S. Regime alimentar para ganho compensatório de ovinos em confinamento: composição regional e tecidual da carcaça. Arquivo Brasileiro de Medicina Veterinária e Zootecnia, Belo Horizonte, v. 65, n. 2, p. 469-476, 2013.

OSÓRIO, J. C. S.; OSÓRIO, M. T. M.; OLIVEIRA, N. R. M.; SIEWERDT, L. Qualidade, morfologia e avaliação de carcaças. Pelotas: Universidade Federal de Pelotas, 2002. $194 \mathrm{p}$.

OSÓRIO, J. C.; OSÓRIO, J.; MENDONÇA, G.; PEREIRA, P.; FARIA, H.; OLIVEIRA, N. Morfologia e características produtivas e comerciais em cordeiros Corriedale castrados e não castrados. Revista Brasileira de Agrociência, Pelotas, v. 11, n. 2, p. 211-214, 2005.
RIBEIRO JÚNIOR, J. I.; MELO, A. L. P. Guia prático para utilização do SAEG. Viçosa, MG: Folha Artes Gráficas Ltda, 2009. 288 p.

SEEBECK, R. M. Developmental growth and body weight loss of cattle. I. Experimental design, body weight growth, and the effects of developmental growth and body weight loss on the dressed carcass and the offal. Australian Journal of Agriculture Research, Collingwood, v. 18, n. 6, p. 1015-1031, 1967.

SNIFFEN, C. J.; O' CONNOR, J. D.; VAN SOEST, P. J. A net carbohydrate and protein system for evaluating cattle diets: II. Carbohydrate and protein availability. Journal of Animal Science, Madison, v. 70, n. 10, p. 3562-3577, 1992.

URANO, F. S.; PIRES, A. V.; SUSIN, I.; MENDES, C. Q.; RODRIGUES, G. H.; ARAUJO, R. C.; MATTOS, W. R. S. Desempenho e características da carcaça de cordeiros confinados alimentados com grão de soja. Pesquisa Agropecuária Brasileira, Brasília, v. 41, n. 1, p. 1525-1530, 2006.

VAN SOEST, P. J.; ROBERTSON, J. B.; LEWIS, B. A. Symposium: carbohydrate methodology, metabolism, and nutritional implications in dairy cattle. Journal of Dairy Science, Madison, v. 74, n. 10, p. 3583-3597, 1991.

WEISS, W. P. Energy prediction equations for ruminant feeds. In: CORNELL NUTRITION CONFERENCE FOR FEED MANUFACTURERS, 61., 1999, Ithaca. Proceedings... Ithaca: Cornell University, 1999. p. 176.

YÃNÉZ, E. A.; RESENDE, K. T.; FERREIRA, A. C. D.; PEREIRA FILHO, J. M.; SILVA SOBRINHO, A. G.; TEIXEIRA, I. A. M. A.; MEDEIROS, A. N. Restrição alimentar em caprinos: rendimento, cortes comerciais e composição da carcaça. Revista Brasileira de Zootecnia, Viçosa, MG, v. 35, n. 5, p. 2093-2100, 2006. 